\title{
Correction to: Cardiovascular Disease Prevention: Training Opportunities, the Challenges, and Future Directions
}

\author{
Anum Saeed ${ }^{1,2} \cdot$ Kaustubh Dabhadkar $^{3} \cdot$ Salim S. Virani ${ }^{1,2,4,5,6} \cdot$ Peter H. Jones $^{2} \cdot$ Christie M. Ballantyne $^{1,2,7}$. \\ Vijay Nambi ${ }^{1,2,4,8}$
}

Published online: 19 June 2018

(C) Springer Science+Business Media, LLC, part of Springer Nature 2018

\section{Correction to: Curr Athero Rep (2018) 20: 35 https://doi.org/10.1007/s11883-018-0735-9}

The original version of this article contains errors in Table 3. "At least 1 project/publication in the year" and " $>1$ publication per year" have been switched under the titles of "Clinical Track" and "Physician-Scientist track".

"At least 1 project/publication in the year" (belongs under Clinical Track Column).

"> 1 publication per year" belongs under the (belongs under Physician-Scientist Column).

There should also be a space between "At" and "least" in the table.

The online version of the original article can be found at https://doi.org/ 10.1007/s11883-018-0735-9

Vijay Nambi

vnambi@bcm.edu

1 Section of Cardiovascular Research, Department of Medicine, Baylor College of Medicine, Houston, TX, USA

2 Center for Cardiometabolic Disease Prevention, Baylor College of Medicine, Houston, TX, USA

3 Division of Cardiology, Department of Medicine, Alpert Medical School of Brown University, Providence, RI, USA

4 Section of Cardiology, Michael E. DeBakey Veterans Affairs Medical Center, Houston, TX, USA

5 Health Policy, Quality and Informatics Program, Michael E. DeBakey Veterans Affairs Medical Center Health Services Research and Development Center for Innovations, Houston, TX, USA

6 The Aga Khan University, Karachi, Pakistan

7 Section of Cardiology, Department of Medicine, Baylor College of Medicine, Houston, TX, USA

86655 Travis Street, Suite 320, Houston, TX 77030, USA 
Table 3 Suggested cardiovascular disease prevention training program outline

\begin{tabular}{|c|c|c|}
\hline Track & Clinical Track & Physician-Scientist Track \\
\hline Duration (years) & 1 & $1-2$ \\
\hline Clinical Exposure $^{\mathrm{a}}$ & \multirow[t]{7}{*}{3 or more half day clinics per week } & \multirow[t]{7}{*}{ 1-2 half-day clinics per week } \\
\hline • Lipid clinic & & \\
\hline - Hypertension & & \\
\hline - Diabetes management & & \\
\hline - Cardiac rehabilitation & & \\
\hline $\begin{array}{l}\text { - Dietician/lifestyle } \\
\text { management } \\
\text { - } \text { Heartfailure }^{\mathrm{b}} \text { Prevention }^{-}\end{array}$ & & \\
\hline $\begin{array}{l}\text { Adolescent preventive } \\
\text { medicine clinic }\end{array}$ & & \\
\hline \multirow[t]{3}{*}{ Research training } & $\begin{array}{l}\text { Basic research methodology and } \\
\text { statistics understanding }\end{array}$ & $\begin{array}{l}\text { Additional; MPH/MSCR Course } \\
\text { Degree/CSTP Course }\end{array}$ \\
\hline & \multirow[t]{2}{*}{ At least 1 project/publication in the year } & $>1$ publication per year \\
\hline & & Grant writing training \\
\hline Conferences/Journal Club & Weekly & Weekly \\
\hline
\end{tabular}

CSTP Clinician-Scientist Training Program, MPH Masters in PublicHealth, MSCR Masters in Science in Clinical Research.

${ }^{\text {a }}$ Clinical exposure includes multiple clinics including but not limited to the mentioned clinical training themes

${ }^{\mathrm{b}}$ Heart Failure Prevention is, at present, not an established clinical model 